\title{
IMPROVING STUDENTS' LISTENING ABILITY THROUGH AUDIO-VISUAL STUDENTS AT CLASS VIII.3 SMPN 3 KEC. PAYAKUMBUH
}

\author{
Yenti Efrina \\ SMP Negeri 3 Kecamatan Payakumbuh, Kabupaten Lima Puluh Kota \\ email: yentiefrina234@gmail.com
}

\begin{abstract}
This research was conducted at SMPN 3 Kec. Payakumbuh in Class VIII.3 where the students' ability to listen to English material is quite low. The purpose of this classroom action research is to find out whether the Audio-Visual learning model can improve student activity and achievement. The method used to collect research data is by conducting observations and learning achievement tests. The method used to analyze the data is descriptive method for both qualitative and quantitative data. The results obtained from this study indicate that the use of Audio-Visual can increase student activity and achievement. This is evident from the results obtained in Cycle I is 50.33 for learning achievement. From Cycle I to Cycle II rose to 74.00 for learning achievement. The conclusion obtained from this study is that the Audio-Visual learning model can improve student achievement.
\end{abstract}

Keywords: Students Listening Ability, Audio-Visual.

\begin{abstract}
Penelitian ini dilakukan di SMPN 3 Kec. Payakumbuh di Kelas VIII.3 dimana kemampuan siswa mendengarkan materi bahasa Inggris cukup rendah. Tujuan penelitian tindakan kelas ini adalah untuk mengetahui apakah model pembelajaran Audio-Visual dapat meningkatkan aktivitas dan prestasi belajar siswa. Metode yang digunakan untuk mengumpulkan data penelitian adalah dengan melakukan observasi dan tes prestasi belajar. Metode yang digunakan untuk menganalisis data adalah metode deskriptif baik untuk data kualitatif maupun kuantitatif. Hasil yang diperoleh dari penelitian ini menunjukkan bahwa penggunaan Audio-Visual dapat meningkatkan aktivitas dan prestasi siswa. Hal ini terlihat dari hasil yang diperoleh pada Siklus I adalah 50,33 untuk prestasi belajar. Dari Siklus I ke Siklus II naik menjadi 74,00 untuk prestasi belajar. Kesimpulan yang diperoleh dari penelitian ini adalah model pembelajaran Audio Visual dapat meningkatkan prestasi belajar siswa.
\end{abstract}

Kata kunci: Kemampuan Mendengarkan Siswa, Audio-Visual.

\section{INTRODUCTION}

Based on the English curriculum for junior high schools, there are four language skills that must be taught to students. The four language skills are; speaking, listening, reading and writing, eventhough the teaching process in 2013 curriculum are done integratively. Those skills are divided into receptive skills (reading and listening) and productive skills (speaking and writing). The four basic competencies must be mastered by students well if they want to develop their communication skills both orally and in writing.

One of the objectives of learning English in junior high school is to develop listening skills. The basic competence of listening in learning English in SMP/MTs is "Compose very short and simple oral and written transactional

ISSN. 1979-6307

FKIP UMSB 
interaction texts that involve giving and asking for informationby paying attention to social functions, text structures, and linguistic elements that are suitable on its context.

Listening skill, as one of the ability to achieve during the lesson, where listeners are required to understand, interpret and evaluate what they hear. The ability to listen actively can improve the interpersonal relationships by minimizing the conflict, strengthening cooperation and developing understanding. Listening is one of the language component that is very difficult to learn by the students. We can see the score got by the students is still low, far from our hope when compared to other language components such as reading and writing.Communication will run better if the listener can respond to what the speaker is talking about. However, most students still have difficulty in hearing because of the different dialects. The difference is not only in terms of pronunciation but also from culture where the language is used.

Among the factors that are caused the low skills of students to understand in English learning techniques that are become the most dominant factor. The teacher continuously introduces English patterns and expressions without going through the right context or situation, and is not followed by practicing and appliying or listening practice. There is very little interaction between students. Therefore, the improvement of speaking skills in English is not optimal.

Sutari, et al. (1997:17) stated that listening has the meaning of paying close attention to what other people say. It is clear that the intentional factor in listening activities is bigger than listening activities because in listening activities there is an effort to understand what is being listened to while in listening activities the level of understanding has not been carried out. Tarigan (1983:19) states that listening is a process to listen to verbal symbols with full attention, understanding, appreciation, and interpretation to attain information, capture content, and understand the meaning of communication that is not conveyed by the speaker through speech or spoken language.

Learning motivation is the pushness or driving force for students both internally and externally in a person to make changes in his/her behavior. Learning motivation can basically help in understanding and explaining individual behavior, including individuals who are learning (Uno, 2007: 27). There are several important roles of motivation in teaching and learning, namely: (1) determining things that can be used as learning reinforcement, (2) clarifying the learning objectives to be achieved, (3) determining the variety of control over learning stimuli, (4) determining persistence study. From the description above, it can be concluded that motivation is very important.

In order to overcome these problems, teachers must keep trying to find ways to solve the problem. Teachers must be able to use several learning methods, especially in teaching listening. And one of the techniques that can be applied to improve students' listening skills is through Audio-Visual. Audio-lingual or Audio-visual is a very interesting method in the listening learning process. Therefore, this method aims for students to be able to understand the target language, able to speak in an acceptable and grammatically correct pronunciation, and be able to understand the teaching materials. Suleiman (1985:11) says that Audio-visual or Audio-lingual is a medium that can be seen and heard in carrying out communication. One of the audio-lingual methods is video. Videos can be 
played according to the material needed. It can be used to watch movies or the film that can improve students' understanding.

Based on the background of the problem above and knowing the weaknesses of students in learning listening and the lack of students' ability to understand listening, so the researchers focused on teaching listening through Audio-isual for students of SMPN 3 Kec. Payakumbuh class 8.3 using audio-visual.

From the analysis of the situation above, the researcher can formulate the problem as follows: Can the listening ability of class VIII.3 students of SMPN 3 Kec. Payakumbuh be improved through Audio-Visual? The aims of this research are: 1) Improve listening skills in English for students at class VIII.3 SMPN 3 Kec. Payakumbuh; 2) To increase activity in learning and teaching listening in English.

This research has done in order to make us able to overcome the problems in speaking class and hopefully can be able to give the benefits for: 1) Students are expected to be more motivated in listening to the conversations in English and provide more opportunities for students to practice listening so that they can improve their abilities by utilizing various learning resources; 2) Teachers are expected to be more creative in applying teaching listening techniques; 3) Because of the importance of using audio-visual media in the process of teaching listening in English, it is hoped that the school can facilitate teachers by providing complete and varied audio-visual media.

\section{RESEARCH METHODOLOGY}

The research conducted to solve the problems appeared during the process of teaching speaking in a classroom. Because of that, the researcher chose Classroom Action Research (CAR) as a research that carried out in the classroom. The reason of choosing this kind of research is that it can help teachers to find out the way to solve the problem emerged as well as to improve the teaching and learning process.

Classrrom Action Research was chosen appropriate with the problems have been exposed in the background of theresearch. The research done followed the model of Kurt Lewin, where the concept of Classrrom Action Research consists of four components; planning, action, observation, and reflection.

This research was carried out at VIII.3 students of SMPN $3 \mathrm{Kec}$. Payakumbuh Lima Puluh Kota Regency. This class is chosed because the researcher teaches in this class. Actually there are six other classes in grade VIII, but the researcher takes this class because the students'listening ability in this class is was still low. The research has done at the first semester 2018/2019 academic year. The schedule of the research adapted to the schedule at SMPN 3 Kec. Payakumbuh Lima Puluh Kota Regency. The research has done for three months (August to October 2018). The participants in this researchwere all students of class VIII.3 SMPN 3Kec. Payakumbuh. There are 31 students, consisting of 14 female students and 17 male students. One female student (got a score of 8 ), two male students (got score 7 and $\& 7.5$ ) had relatively good abilities, one male student (6.5) and 2 female students (6.5 and 6) had medium ability and the rest have very low ability (below 6). 
The data of this research are sourced from students and teachers. Data from students werethe test results, both initial and final tests that can be observed directly by researchers and her colleagues, and activities in the learning process. Data from the teacher is the result of observations made by the researchers when the teaching and learning process is taking place as additional data in this study.

The data obtained in each action was analyzed quantitatively and qualitatively to determine the final result of an action. Qualitative data on student learning outcomes was analyzed descriptively by finding the average score of student success in both pre-test and post-test. The data from the evaluation was analyzed using descriptive analysis by finding the average score of student success in both the pre-test and post-test. That is by using the following steps:

1. The score of each student answering the test in each meeting.

2. The data is calculated by the following formula:

Where:

$$
\bar{x}=\frac{\sum x}{N}
$$

$\bar{x} \quad=$ The average score achieved by students on the test.

$x \quad=$ The total number of values.

$N=$ Number of students.

Meanwhile, qualitative data obtained through observation sheets were analyzed so that they can provide an overview of the level of understanding of the lesson, attitudes or views of students towards the applied learning methods, student activities in following lessons, attention, enthusiasm in learning, selfconfidence, learning motivation, and excetra were analyzed qualitatively.

This research was conducted using classroom action research (CAR). There are four stages that are commonly passed in this classroom action research, namely (1) Planning, (2) Implementation, (3) Observation, and (4) Reflection (Arikunto, 2007: 11). The four steps above are described in detail as below.

\section{Planning}

At this stage the researcher compiled and designed actions that were carried out to improve students' listening comprehension skills and students' low motivation to learn. Based on the the result of the pre-test, the average score of students is only 4.98 with low enthusiasm and motivation to learn. The action plan that was given to students only takes place in 2 cycles within a period of $12 \times 40$ minutes.

The action plan implemented in this stage was a learning design that was developed based on the problems found and the learning method used, namely Audio-Visual to solve the problem of students' low listening comprehension and their learning motivation.

\section{Action}

In this step, the researcher took learning steps by applying Audio-Visual techniques in accordance with the learning design that has been prepared in the first step. Students are guided to improve their understanding effectively and efficiently and improve memory performance in understanding the content of the conversation. 
The first step was the first video with the topic "Always remember to say please" was played to students by giving some brainstorming to increase students' interest in learning. After the video has been played for 2 times, then students are asked to answer some general questions according to the video that was being played. Then the researcher invited students to discuss each answer to each question given.

After the discussion was over, the second video with the topic "Cheers... hicccuupp" was played 2 times. Then students were asked to answer the questions given by the presenter orally but the questions given this time were more detailed related to the video being played.

The next step, students were shown a video with the topic "Long time no see and Jeffry doesn't live here" twice. After the video is finished playing, then students are given a multiple choice test and students are given the opportunity to answer the question.

After all student answers have been collected, then students are given a script from the first video to the last video, then students are asked to perform (perform) each video that was previously played in front of the class.

The steps above are the essence of the treatment given to students to improve their understanding in listening to English. Thus, student learning outcomes using Audio-Visual techniques can be expected to be more satisfying and can improve students' listening skills.

\section{Observation}

Observations were made while the action was running. The researcher records all the things that are needed and occur during the implementation of the action. Data collection was carried out using tests and observation sheets that had been prepared previously. The data collected was in the form of quantitative data from student test results and qualitative data derived from observation sheets. Other important things related to action are also noted in this step. The format of the observation during the action process is as follows.

Table 1. Observation Process Format

\begin{tabular}{|l|l|l|l|l|}
\hline No & \multicolumn{1}{|c|}{ Observation Objects } & Good & Enough & Less \\
\hline 1. & Students' when receiving orders & & & \\
\hline 2. & $\begin{array}{l}\text { Students' seriousness in the process of } \\
\text { actions }\end{array}$ & & & \\
\hline 3. & Students' feedback & & & \\
\hline 4. & Learning situation & & & \\
\hline 5. & The effectiveness of learning media & & & \\
\hline 6. & Students' response in receiving orders & & & \\
\hline 7. & Punctuality & & & \\
\hline 8. & Students' motivation toward learning & & & \\
\hline 9. & The changing of students' attitude & & & \\
\hline 10. & Self confidence & & & \\
\hline 11. & Skill upgrade & & & \\
\hline
\end{tabular}

\section{Reflection.}

This stage is intended to review the actions thoroughly that have been taken, based on the data that has been collected in the previous steps and look for the difficulties experienced by students and teachers in the process of action 
that has been taken. Students are invited to discuss in each cycle to ask about the difficulties they are experiencing. While the teacher reflects back on past events when the action process took place. All data obtained were analyzed and evaluated to complete the action in the next cycle or whether or not the treatment given to students was continued.

\section{FINDINGS AND DISCUSSION FINDINGS}

This chapter presents the description of the activities done in two cycles and findings that got during the research. In conveying the results of research and discussion, it is necessary to present a description of each cycle with complete data ranging from planning, implementation, observation and reflection which contains an explanation of the aspects of success and weakness that occurred. It is necessary to add basic things, namely the results of the discussion (progress) in students, the environment, teachers, motivation and learning activities, class situations and learning outcomes, put forward graphs and tables of data analysis results that show changes that occur accompanied by systematic and clear discussions (Suharsimi Arikunto, Suhardjono, Supardi, 2006: 83).

\section{Cycle I}

\section{Action Plan}

The results obtained from planning activities include:

a. Develop a further action plan complete with a Learning Implementation Plan (RPP) which will be implemented with Audio-Visual. Based on the initial results of the VIII.3th grade students' abilities listed on the backgrounds, the researchers planned more intensive activities such as consulting with peers and school principals about preparing for the implementation of learning using Audio-Visual techniques.

b. Determine the implementation time, which involves the day, date, according to the research schedule, in the 2nd week of October.

c. Develop a check format related to Audio-Visual learning.

d. Ask another English teacher as a collaborator to observe learning during the research and observe all activities carried out by teachers and students

e. The researcher explained to the students that the presence of the supervisor to the class was not to find faults or weaknesses of the teacher in learning, but to improve the students' ability to master knowledge.

f. Planning lesson materials and formulating goals. Determining the lesson material, by adjusting to the applicable syllabus and its description quite well.

g. Selecting and organizing materials, media, and learning resources.

In this first cycle, the researcher organized the learning materials well. The materials taughtwas ordered from easy to difficult, the scope of the material is quite meaningful for students, determines teaching aids. Meanwhile, in determining learning resources, it has been adjusted to the objectives, learning materials and the level of development of students.

h. Designing learning scenarios.

Learning scenarios are adjusted to the objectives, material and level of student development, and variations in teaching. 


\section{Implementation of Action}

a. Class Management

Manage the class with careful preparation, teach the material correctly according to the Audio-Visual learning model.

b. Assessment Tool

The discussion and types of assessment are attached to the RPP along with the assessment format.

c. Appearance

In general appearance, researchers dress neatly, use polite language, guide students as much as possible by using the Audio-Visual learning method. Researchers seek strategies to easily observe students who are learning. After the learning process is completed, it was continued by holding a meeting with the collaborator teacher who supervised the learning process to discuss the results of the observations made.

d. From discussions with teachers, it was revealed that:

1) The learning that has been done has not been maximized, because this is the first time researchers have tried this method.

2) Students are not yet actively receiving lessons and giving feedback, this was in accordance with the purpose of the Audio-Visual method.

3) The researcher proposed that the teacher who observed was willing to return and was willing to observe again on opportunities in cycle II.

4) The submission of the observer to the researcher can be conveyed needed better management of space, time, and learning facilities.

In managing the classroom, time and learning facilities, it can be described as follows:

1) Researcher provided learning tools/media.

2) Researcher paid less attention to the cleanliness of the blackboard, the cleanliness of student uniforms, in other ways that are useful for fostering student motivation and discipline.

3) Researchers have not used time effectively and efficiently.

\section{Observation}

The observations made varied greatly. The researcher used collaborator teachers to join the class to observe the correctness of the implementation of learning activities using the Audio-Visual model. The data obtained from the observation activities carried out by the teacher was greatly affect the progress of the researcher in implementing the Audio-Visual learning model considering that all the weaknesses of the researcher have well observed. If the researcher connected it with the so-called intervening variable where there were certain things that can affect the relationship between the independent variable, namely the Audio-Visual learning model and the dependent variable, namely learning achievement. The particular thing that was discussed was the correctness of the implementation of the Audio-Visual learning model. If the implementation was not done properly, it certainly affected the learning outcomes.

Observations by collaborator as described above are very necessary for the success of improving the quality and correctness of learning the Audio- 
Visual model. This was what researcher done for the sake of innovation efforts so that scientific writing was more efficient and effective.

The observations made by colleagues, another effort that the researcher made was to ask one of the smart students to check whether the implementation of Audio-Visual learning in the classroom had gone as expected or not. Both the teacher who observed, and the students who was interviewed the activities of their friends, had previously been called to the office and given an explanation about the truth of the implementation of Audio-Visual learning that demands creativity; self-discovery by students; emphasis on intellectual activity; process learning experiences into something meaningful in real life; familiarize students to be more productive, analytical, critical; the use of methods, techniques, and strategies that enable students to seek and find their own answers optimally.

In addition, this model demanded problem-solving skills to increase intellectual satisfaction, sharpen memory processes for longer mastery, more student-centered learning, self-concept development and academic talent, avoid learning by rote, grow the ability to assimilate and accommodate information. The learning steps are: a) formulating questions to be able to conduct research, b) checking whether the results of student observations can answer questions, c) collecting data/information, d) analyzing information, e) making conclusions based on the results of information analysis. . From all the definitions above, researchers have prepared instruments for the accuracy of the implementation brought by teachers and students who observe the learning process.

\section{Reflection}

Before starting reflection, it's good to see the opinion of education experts about what is meant by reflection. This opinion was a guide on how or what was necessary in writing reflections. Reflection is a thorough study of the actions that have been taken based on the data that has been collected, then an evaluation was carried out in order to perfect the actions. Reflection involves analysis, synthesis, and assessment of the results of observations of the actions taken (Hopkin, 1993 in Suharsimi Arikunto, Suhardjono, Supardi, 2006: 80).

For the recapitulation of the results of this study, it was be presented at the same time at the end of the reflection analysis at cycle II. For the results of the analysis of teacher observations and student observations of the correctness of the implementation of Audio-Visual learning. For the two observations, the results can be conveyed as follows: observations by teachers I colleagues in the form of notes on the shortcomings of researchers when carrying out the Audio-Visual learning process, this is a very valuable input for improvement in the next cycle, for this more details can be seen in discussion. In addition, it has been seen that the team is capable, the team that is not capable, has clearly shown activeness, tenacity, creativity, looking for the important things assigned, showing activity skills, being critical, it is true that students are active in learning and not teachers who are actively teaching, the ability to demonstrate self-concept, responsiveness and ability to draw conclusions. All of that has been seen that there are changes and 
improvements when researchers use audio-visual in English listening activities.

Judging from the results of the quantitative data, the total score of all students in the pre-test was 1510, and the total score in session 1 was 1780 , while the score in session 2 was 2220, after being averaged, the score obtained was 50.33 for the pre-test value, 59.33 for the value of session 1, and 74 for the value of session 2 from the analysis made, it can be concluded that the results obtained have shown the success of learning when using Audio-Visual which is done by the teacher.

\section{Cycle II}

\section{Planning}

Seeing all the results obtained in cycle I, for planning the implementation of research in cycle II, there are several things that need to be done, namely:

a. The researcher planned to re-plan the schedule for conducting classroom learning by looking at the research schedule in Chapter III and the time in the education calendar. The results of the reflection in cycle I are the basis for planning in cycle II.

b. Developed a good learning implementation plan according to the AudioVisual learning model and make data collection instruments, namely learning achievement tests.

c. Planning class visits with observation friends as an innovation effort. For this the researcher consulted asking for his willingness to participate in the learning process carried out. This innovation is carried out so that researchers can make maximum efforts to carry out better and higher quality learning. The result of consultation with colleagues was the readiness of the teacher to participate in supervising classroom visits. The teacher who observed was told that the researcher has consulted with the principal and he participated, entering the room to join supervision. This was notified to the teacher in the hope that the teacher who observed could be better prepared to carry out higher quality supervision, this was also done by the researcher as an additional innovation.

d. Teacher as the researcher, designed a scenario for the implementation of learning by looking at the shortcomings in cycle I by identifying things that could be done to improve learning. For this matter, all notes about the shortcomings in cycle I which were the result of reflection were submitted to the teacher for the study. Tell the teacher what needs to be done, what students must do, how to apply the correct Audio-Visual method according to the truth of the theory presented.

\section{Action}

The implementation of the actions in cycle II is presented as follows:

The first step was presented the first video with the topic "I Want to Fly" was shown to students by giving some brainstorming to increase students' interest in learning. After the video has been played for 2 times, then students are asked to answer some general questions according to the video that is being played. Then the researcher asked the students to discuss each answer to each question given. 
After the discussion was over, the second video with the topic "How Do I Get To Nanjing Road" was played for 2 times. Then students were asked to answer the questions given by the presented orally but the questions given this time were more detailed related to the video being played.

The next step, students were shown a video with the topic "Are You Busy and What A Fat Bird" twice. After the video is finished playing, then students are given a multiple choice test and students are given the opportunity to answer the question.

After all student answers have been collected, then students are given a script from the first video to the last video, then students are asked to perform each video that was previously played in front of the class.

The steps above are the essence of the treatment given to students to improve their understanding in listening to English. Thus, student learning outcomes using Audio-Visual techniques can be expected to be more satisfying and can improve students' listening skills.

At the second meeting, the learning activities continued with the discussion of new topics. In this activity, students were shown 4 videos entitled "Sign language, How do I get Nanjing Road, Long Farewell and What Do You Do". At the beginning of the activity, students were shown two videos entitled "Sign Language and How do I get Nanjing Road". The teacher gives brainstorming to students to introduce a video about "Sign Language and How do I get Nanjing Road". The teacher gave several questions related to the video that was played as a stimulus. All these questions are discussed classically and orally so that students are carried away in a fun learning situation.

Then the teacher asked students to watch a video entitled "Long Farewell and What Do You Do" independently with 10 question items given which included aspects of finding general ideas, finding specific information, finding detailed information, and word meanings. This test was also a test to determine student progress in this first cycle of action and students are given 15 minutes. Thus the learning steps in the second cycle of action process by applying Audio-Visual Techniques within 4 x 40 minutes ( 2 x meetings).

\section{Observation / Assessment}

The assessment of the correctness of the implementation of AudioVisual learning was preceded by noting important things such as learning activities carried out when the researcher took action. From these notes, the researcher knew which parts needed to be improved, where emphasis is needed, which parts need suggestions and reinforcements. In addition, having a teacher who observed the learning process will be very helpful to find out more clearly the mistakes made during the learning process. The teacher who observed also notes the creativity of students, the willingness of students to participate in learning, contributions among students. All of this has been done well. The implementation of the learning achievement test was finally continued because after the teacher carried out the learning process, there was not enough time to give the test so it was carried out at the next meeting. The results of the second cycle of student achievement tests was discussed in the second reflection. 


\section{Reflection Cycle II}

Judging from the results of the quantitative data, the total score of all students in the pre-test was 1515, and the total score in session 3 was 2205, while the score in session 4 was 2485, after being averaged, the score obtained was 50.50 for the pre-test value, 73.5 for the value of session 2, and 82.83 for the value of session 4 from the analysis made, it can be concluded that the results obtained have shown the success of learning when using Audio-Visual which is done by the teacher.

\section{DISCUSSION}

\section{Discussion of the results obtained from Cycle I}

Things that need to be considered in discussing qualitative data on the observations of collaborator teacher about Audio-Visual learning are: existing weaknesses, strengths, changes, advances, time effectiveness, activities carried out, construction, contribution, fact description, checking internal validity and external validity, problem identification, influencing factors, ways to solve problems, considerations, comparisons, comments, responses, additional experiences, summary, opinions - opinions, descriptions, interpretations/interpretations, meaning behind actions, triangulation, relations between aspects, classifications, standards of value determination, reasons for using certain techniques, reasons for using certain steps, classifications, combining -combination, tabulation, usage, criteria, categorization, meanings, relationships interest between categories.

From the observations of the collaborator teacher, it was conveyed that there were advantages conveyed by the researcher were neatly dressed, used polite language, guided students well. These things rise to the interpretation that the research journey has been quite good. The weaknesses presented need to be analyzed, namely the use of time that has not been effective, construction, student contributions have not been maximized, this fact will be used as a reference for the truth of the data, validation, internally taken from informants are accounted for, external validity in the form of legal references used theories that support and the reliability of this research data can be trusted because it is the accuracy of researcher choosing informants, namely colleagues. The factors that influence were not yet maximal in the first cycle because the researcher has only tried this model once. The way to solve the problem was to prepare better, higher quality lesson plans. Other things such as comments, additional experiences, descriptions of the success of the research will be seen in the results of the next cycle. So, few qualitative results or quality of learning with the Audio-Visual model.

\section{Discussion of the results obtained from the learning achievement test cycle}

I

The results of the learning achievement test which are oral tests and multiple choice tests were forced students to be really understand what they have learned. The average score of students in the first cycle was 59.33 in the first session and 74.00 in the second session, indicating that students have begun to master the material being taught although not yet perfect. These results indicate an increase in students' ability to master English subjects, 
especially in listening skills when compared to the initial value of students' pretest scores.

The results of the learning achievement test in the first cycle have found the main effect that the use of certain methods will affect student achievement, which in this case was the Audio-Visual method. This is in accordance with the results of the meta-analysis of learning methods conducted by Soedomo, 1990 (in Puger, 2004) which states that the learning method applied by a teacher affects his learning achievement.

As we all known, English subjects emphasized learning on cognitive, affective, and psychomotor aspects as a guide to students' daily life behavior. For solving existing difficulties, the use of this method can help students to be creative, act actively, exchange ideas, express opinions, ask questions, discuss, argue, exchange information and solve problems that exist together with members of the discussion group. This is what makes students think sharper, more creative and critical so that they are able to solve complex problems and the next effect is that students will be able to understand and can be easily understand English subjects further.

The remaining handicaps that needed to be discussed is that the learning achievement achieved in cycle I has not met expectations in accordance with the demands of the KKM for English subjects at the research school, which is 75. In the initial test, only 2 out of 30 students completed, while in the first session in the first cycle it increased to 5 people and continued to increase to 9 people in the second session. Therefore, further improvement efforts still need to be pursued so that more careful planning is needed for the next cycle.

\section{Discussion of the results obtained from Cycle II}

The results obtained from the learning achievement test in cycle II showed that the students' ability to follow the lessons was quite good. This is evident from the average score of students reaching 73.50 in session 3 and 82.83 in session 4 . So the average score of students in the second cycle is 78.17. The number of students who completed the listening test in the third session of the second cycle was 10 students, an increase of 1 person compared to the second session. In the fourth session the number of students who completed increased to 29 students. So in the fourth session there was a very significant increase.

These results indicate that the Audio-Visual method has succeeded in improving students' listening skills in English. Audio-Visual was a suitable model for students if the teacher wanted them to have the ability to be creative, argue, express opinions in a straightforward manner, exchange ideas, argue, remember. The use of this method was to foster students' intellectual abilities, encourage students to be able to find themselves, put students in a central position and try to prevent students from learning by rote.

The results of this study turned out to have given the main effect that the model applied in the learning process had a significant effect on student achievement. This finding proves that the teacher has chosen the right method in carrying out the learning process because the choice of method is something that cannot be ruled out. This is also in line with the findings of other 
researchers such as those of Inten (2004) and Puger (2004) which basically state that the applied learning methods affect student achievement.

The English subject focused on the cognitive, affective and psychomotor aspects as a guide for students' abilities in terms of thought, behavior and visuals, which occupy an important place because they can activate students optimally. From the score obtained by the students, more than half of the students got a score of 80 . From the comparison of these scores, it can be believed that student learning achievement can be improved by using the Audio-Visual method.

Looking at the comparison of the initial value, the value of the first cycle and the value of the second cycle, there was a significant increase, namely from the average initial value of 50.33, it rose in the first cycle to 59.33 and in the second cycle it rose to 74 underestimated because this increase in value was the result of the maximum efforts carried out by researcher to improve the quality of education and the advancement of education, especially at SMPN $3 \mathrm{Kec}$. Payakumbuh Lima Puluh Kota Regency.

\section{CONCLUSION AND SUGGESTION}

By knowing that the trigger for low learning activities and learning achievement was on factors such as the method used by the teacher, so that the use or replacement of conventional methods into constructivist methods was very necessary, as a result, researcher tried Audio-Visual learning models in an effort to solve problems at school. Based on the low learning activity and student achievement presented on the background of the problem, the use of the AudioVisual learning model was attempted to be able to complete the purpose of this study, namely to determine the increase in student achievement.

To answer the research objective, namely the achievement of an increase in student achievement, it can be seen the evidence that has been submitted.

1. From the initial data, only 2 out of 30 students scored above the KKM standard, then in the first cycle of session 1 increased by 5 students, in session 2 increased to 9 students. In cycle II, session 3 increased by 1 person who completed compared to session 2, while in session 4 there was a significant increase, where 29 people completed the listening test after using audio-visual during the learning process.

2. From the initial average value of 50.33 , it rose to 59.33 in the first cycle and in the second cycle it rose to 74.00 .

3. From all the supporting data, it was proven that the achievement of learning objectives can be conveyed that the Audio-Visual model can provide the expected answers according to the objectives of this study. All of this can be achieved as a result of the readiness and hard work of researchers from the time of making proposals, reviewing things that are not yet good with fellow teachers, preparing research grids and instruments, using data triangulation facilities to the maximum implementation of research.

4. From the initial average value of 50.33, it rose to 59.33 in the first cycle and in the second cycle it rose to 74.00 .

From all the supporting data, it was proven that the achievement of learning objectives can be conveyed that the Audio-Visual model can be 
provided the expected answers according to the objectives of this study. All of this can be achieved as a result of the readiness and hard work of researchers from the time of making proposals, reviewing things that are not yet good with fellow teachers, preparing research grids and instruments, using data triangulation facilities to the maximum implementation of research.

5. Although this research has been able to prove the main effect of the AudioVisual model in increasing learning activity and achievement, it is certain that in this study there are still things that have not been perfectly done, therefore other researchers who are interested in researching the same topic to research parts that have not been studied.

Based on the findings that have been concluded from the research results, in an effort to achieve learning objectives in the field of English studies, the following suggestions can be submitted:

1. If you want to carry out the learning process in English subjects, the use of the Audio-Visual learning model should be the choice of several existing methods considering that this method has been proven to increase collaboration, be creative, act actively, exchange information, express opinions, ask questions, argue and etc.

2. Although this research has been able to prove the main effect of the AudioVisual model in increasing learning activity and achievement, it is certain that in this study there are still things that have not been perfectly done, therefore other researchers who are interested in researching the same topic to research parts that have not been studied.

\section{REFERENCE}

Arikunto, Suharsimi; Suhardjono; Supardi. 2006. Penelitian Tindakan Kelas. Jakarta: PT BumiAksara.

Sutari, et al. 1997. Menyimak Bersama. Jakarta: Gramedia.

Tarigan, Henry Guntur. 1983. Menyimak: Sebagai Suatu Keterampilan Berbahasa. Bandung : Angkasa.

Suleiman, Amir Hamzah. 1985. Media Audio Visual Untuk Pengajaran, Penerangan, Penyuluhan. Jakarta: Gramedia.

Arikunto, Suharsimi dkk. 2007. Penelitian Tindakan Kelas. Jakarta: Bumi Aksara. Uno, Hamzah. 2007. Teori Motivasi dan Pengukurannya. Jakarta: Bumi. Aksara 